Indonesian Journal of Global Health Research

Volume 3 Number 1, February 2021, pp. 1 - 8

e-ISSN 2715-1972; p-ISSN 2714-9749

http://jurnal.globalhealthsciencegroup.com/index.php/IJGHR

\title{
THE ANALYSIS OF CHITOSAN GRANULES OF POLYMESODA EROSA ON CATFISH
}

\author{
Ariyanti*, Eni Masruriati, Lina Lisiana Pasha, Dina Arlidina \\ Program Studi S1 Farmasi, Sekolah Tinggi Ilmu Kesehatan Kendal, Jln Laut 31A Kendal, Jawa Tengah, \\ Indonesia 51311 \\ *riri99.cettaazzahra@gmail.com
}

\begin{abstract}
These abundant polymesoda erosa are only a waste for the community and have not been widely used by the community. Polymesoda erosa waste can be used because it includes local raw materials that are easily available and often found as waste for the community. The compounds contained in the shells of polymesoda erosa are chitin, calcium carbonate, calcium hydroxyapatite and calcium phosphate. This research was conducted to utilize the waste of polymesoda erosa as a granule supplement for catfish feed. The purpose of this study was to determine the most optimal concentration of chitosan waste granules from polymesoda erosa shells as catfish feed. This research is a laboratory experimental study using a completely randomized design with 5 treatments. The treatment applied was the difference in the concentration of chitosan shells from polymesoda erosa shells by $15 \%, 25 \%$, and $35 \%$, with negative control and positive control. The parameter in this study was the increase in weight of catfish. Observations were made for 1 month by feeding 3 times. To determine the existence of a comparison, a statistical test was carried out using One Way Anova test. The results showed that the optimal concentration of chitosan granules from polymesoda erosa waste was at the concentration of $35 \%$ by observing the development of fish weight.
\end{abstract}

Keywords: catfish feed supplements; chitosan granule; crab shells

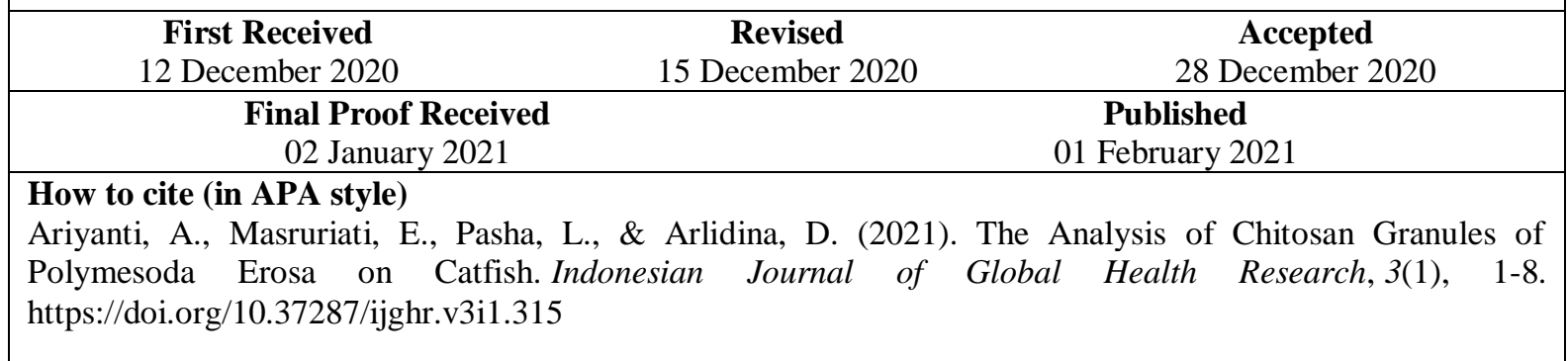

\section{INTRODUCTION}

One of the sea animals is polymesoda erosa. Mussels have polymesoda erosa waste. These abundant polymesoda erosa are only a waste for the community and have not been widely used by the community (Kasim 2013). Polymesoda erosa waste can be used because it includes local raw materials that are easily available and often found as waste for the community. There are quite a lot of waste from polymesoda erosa when the sea is tide at Sikucing beach in Rowosari, Kendal District.

The compounds contained in the shells of polymesoda erosa are chitin, calcium carbonate, calcium hydroxyapatite and calcium phosphate. The results of the processing of chitin compounds are used as chitosan. Chitosan is a polysaccharide amine resulting from chitin distillation (Afranita, Anita 2014). The utilization of chitosan polymesoda erosa waste in fisheries can be used as a natural alternative to catfish food. The use of natural ingredients of chitosan shells as catfish feed can increase the productivity of catfish (T. Masindi and $\mathrm{N}$. Herdyastuti 2017). 
Therefore, the researchers made an alternative catfish feed using materials from the polymesoda erosa waste which is easier to obtain and is expected to be beneficial to increase catfish weight. The purpose of this study was to determine the optimal concentration of Polymesoda erosa granules.

\section{METHOD}

\section{Material}

The materials used in this research were polymesoda erosa, $\mathrm{NaOH}, \mathrm{HCL}, \mathrm{NaOH}$ solution, aquadest, chitosan, glycerin, bran and CMC-Na.

\section{Tool}

The tools used in this study were analytical scales, cupboards, blenders, bunsen and tripods, thermometers, $\mathrm{pH}$ indicators, Erlenmeyer's, measuring cups, beaker glass, glass funnels, porcelain cups and watch glasses.

\section{Preparation of raw material for polymesoda erosa shells}

First, the shells were washed under running water and dried under the sun for 8-12 hours or in a drying cupboard with a temperature of $80^{\circ} \mathrm{C}$ for 24 hours so that the dry product was obtained with a moisture content of $\pm 10 \%$. The shells were then crushed and sieved using a sieve number 60 to get the particle size of $\pm 3 \mathrm{~mm}$.

\section{Deproteinization}

The shells were weighed then mixed with $3 \% \mathrm{NaOH}$ in a ratio of $1: 5$, then heated at $60-70^{\circ} \mathrm{C}$ for two hours. The solution of the coconut shells was cooled down and filtered to obtain solids. The solids of the polymesoda erosa were washed with water to neutral $\mathrm{pH}$, then dried at $60^{\circ} \mathrm{C}$ for 36 hours (Ariyanti et al. 2019).

\section{Demineralization}

The shells that have gone through the deproteinization process were mixed with HCL $1.25 \mathrm{~N}$ with a ratio of 1: 5 . The mixed solution of the polymesoda erosa mixture was then heated at $60-70^{\circ} \mathrm{C}$ for two hours. The solution was then filtered to obtain a solid, then washed with water until the $\mathrm{pH}$ was neutral. The solids of the polymesoda erosa were then dried in an oven at $60^{\circ} \mathrm{C}$ for 36 hours. The resulting chitin shells were stored in a plastic bag ready for use (Ariyanti et al. 2019).

\section{Deacetylation}

The chitin shells obtained were added with $25 \% \mathrm{NaOH}$ in a ratio of 1: 5 , and heated at 60 $70^{\circ} \mathrm{C}$ for two hours. The solution was then filtered to obtain a solid, then washed with water until the $\mathrm{pH}$ is neutral. The solid was dried in an oven at $60^{\circ} \mathrm{C}$ for 36 hours. The chitosan shells obtained were weighed and stored in a plastic bag at room temperature (Ariyanti Ariyanti et al. 2019).

\section{Preparation of granule preparations}

The chitosan shells that have been obtained were then made granules with 3 concentrations, namely $20 \%, 25 \%, 30 \%$ with negative control and positive control. In this study, the negative control used was catfish pellet feed which is commonly used, while for the control positive, it used blood clam shell chitosan. Feeding the fish with the addition of chitosan granules in the shell of polymesoda erosa was carried out twice a day during maintenance. 


\section{Evaluation of granule preparations \\ Granule moisture content}

Determination of water content of granules chitosan shells was done by calculating the drying loss and moisture content. A total of 5 grams of granule was weighed and heated in a drying cabinet to constant weight $\left(105^{\circ} \mathrm{C}\right)$ for 2 hours.

\section{Compressibility test}

The weight of $25 \mathrm{~g}$ of chitosan granules in the polymesoda erosa shells was then put into a measuring cup and the volume recorded (initial volume). The measuring cup was tapped at the height of $2.5 \mathrm{~cm}$ in 2 second intervals. Every 10 beats, the volume was recorded until the volume was constant (volume compressed).

\section{Bulk density test}

The granules of chitosan shells were weighed as much as $25 \mathrm{~g}$ and put into a measuring cup and recorded the volume (initial volume). Bulk density is the weight of the granule divided by the initial volume.

\section{pH test of the granule preparation solution}

The chitosan shells of the polymesoda erosa shells were weighed as much as $4 \mathrm{~g}$, put in a beaker glass, then added by distilled water, wait until the granules dissolved all. Then, the $\mathrm{pH}$ of the solution was checked using a Ph meter.

\section{Test of the granule dissolving time velocity}

The dissolution was calculated with a stop watch starting from the granules immersed in the aquadest until all the granules were dissolved.

The chitosan granules for catfish feed was given for 3 times, namely morning, afternoon and evening then the development of catfish was observed for 30 days. After the chitosan granules was given, it was then compared to positive control.

\section{Data analysis}

In this study, ANOVA was done, followed by post hoc test analysis to determine whether there was a difference in the average of each group of polymesoda erosa chitosan granules.

\section{RESULTS}

Table 1.

Yield of chitosan shells

\begin{tabular}{ccccc}
\hline $\begin{array}{c}\text { Weight of } \\
\text { sample }(\mathrm{g})\end{array}$ & $\begin{array}{c}\text { Weight of } \\
\text { deproteination } \\
(\mathrm{g})\end{array}$ & $\begin{array}{c}\text { Weight of } \\
\text { demineralization / } \\
\text { Weight of chitin } \\
(\mathrm{g})\end{array}$ & $\begin{array}{c}\text { Weight of } \\
\text { deacetylation / } \\
\text { weight of } \\
\text { chitosan }(\mathrm{g})\end{array}$ & $\begin{array}{c}\text { Yield of } \\
\text { chitosan }(\%)\end{array}$ \\
\hline 1000.00 & 770.24 & 750.33 & 680.33 & 77.66 \\
\hline
\end{tabular}

Table 1, the results of chitin weight were $750.33 \mathrm{~g}$ from the initial weight of $1000 \mathrm{~g}$ polymesoda erosa samples. In the deptoteination process, the yield was $770.24 \mathrm{~g}$. The process of obtaining clamshell chitosan was obtained $680.33 \mathrm{~g}$, which is equivalent to $77.66 \%$ yield of chitosan shells. 


\section{Results of Evaluation of Crust Shell Chitosan Granule Formulation Organoleptic test}

Organoleptic testing of chitosan granule preparations in the shell of polymesoda erosa obtained brown granules, in which the higher the concentration, the more dark brown the granules would be.

\section{Moisture content test}

The test was done on the moisture content and drying shrinkage of the granules. The results showed that the negative control was the most humid of all the concentrations of chitosan shells.

\section{Compressibility test and porosity value}

The compressibility value of the formula above showed that at the value of $15 \%$ it was in the good category, while at the value of $16 \%$ it was not in the good category, but was close to the good category.

\section{Granule Preparation pH Test}

The results of $\mathrm{pH}$ measurement showed that the average $\mathrm{pH}$ of the four formulas ranged from 6.45 to 6.50 . The $\mathrm{pH}$ of the preparation is considered to be good if the $\mathrm{pH}$ is close to neutral, namely 6-7.

\section{Granule dissolving time test}

The results showed that the four formulas met the good granule requirements. The results of the four formulas were 03:12, 03:10, 03:14, 03:15 which showed that the chitosan granules of the polymesoda erosa met the requirements for good granule dissolving time.

Table 2.

Results of Testing of Chitosan Granule Formulas in Crustaceans Against Catfish

\begin{tabular}{cccccc}
\hline Week & \multicolumn{5}{c}{ Formula } \\
\cline { 2 - 6 } & $\begin{array}{c}\text { Positive } \\
\text { control 10\% }\end{array}$ & $\begin{array}{c}\text { Negative } \\
\text { control } 15 \%\end{array}$ & $\begin{array}{c}\text { concentration } \\
15 \%\end{array}$ & $\begin{array}{c}\text { concentration } \\
25 \%\end{array}$ & $\begin{array}{c}\text { concentration } \\
\text { Initial } \\
\text { weight }\end{array}$ \\
\hline $10 \mathrm{~g}$ & $73 \mathrm{~g}$ & $73 \mathrm{~g}$ & $74 \mathrm{~g}$ & $74 \mathrm{~g}$ \\
\hline 1 & & & & & \\
\hline 2 & $120 \mathrm{~g}$ & $90 \mathrm{~g}$ & $96 \mathrm{~g}$ & $98 \mathrm{~g}$ & $106 \mathrm{~g}$ \\
\hline 3 & $140 \mathrm{~g}$ & $109 \mathrm{~g}$ & $124 \mathrm{~g}$ & $145 \mathrm{~g}$ & $153 \mathrm{~g}$ \\
\hline 4 & $167 \mathrm{~g}$ & $136 \mathrm{~g}$ & $176 \mathrm{~g}$ & $211 \mathrm{~g}$ & $222 \mathrm{~g}$ \\
\hline Average & 117.4 & 107.2 & 122.2 & 137.2 & 144 \\
\hline SD & 1.21 & 1.01 & 1.23 & 1.02 & 1.12 \\
\hline
\end{tabular}

The results from the data table 2 show that catfish's weight has increased in each week. The increase in weight at a concentration of $35 \%$ was the most stable increase compared to other treatments. This shows that the concentration of $35 \%$ of chitosan was the most optimal formulation for increasing the catfish weight.

\section{SPSS Analysis Test Results}

The results of the SPSS analysis test were in the form of normality tests, while the homogeneity was fulfilled as the ANOVA test requirements. The results of anova and post hoc tests can be seen in table 3 and table 4 . 
Table 3.

ANOVA analysis results of weight enhancement test of catfish against chitosan of polymesoda erosa shells

\begin{tabular}{cccc}
\hline F & Signification & Information & Conclusion \\
\hline 18.971 & 0.000 & Sig. $>0.05$ & Mean not identic \\
\hline
\end{tabular}

Table 4.

Results of Post Hoc Test Analysis

\begin{tabular}{|c|c|c|c|c|}
\hline Concentration & concentration & Signification & Information & Conclusion \\
\hline \multirow[t]{3}{*}{ Positive control } & $15 \%$ & 0.889 & Sig.> 0.05 & Mean not identic \\
\hline & $25 \%$ & 0.126 & Sig.> 0.05 & Mean not identic \\
\hline & $35 \%$ & 0.016 & Sig. $<0.05$ & Identic mean \\
\hline \multirow[t]{4}{*}{ control negative } & pellet & 0.023 & Sig. $<0.05$ & Identic mean \\
\hline & $15 \%$ & 0.009 & Sig. $<0.05$ & Identic mean \\
\hline & $25 \%$ & 0.000 & Sig. $<0.05$ & Identic mean \\
\hline & $35 \%$ & 0.000 & Sig. $<0.05$ & Identic mean \\
\hline \multirow[t]{4}{*}{$15 \%$} & Pure pellet & 0.969 & Sig.> 0.05 & Mean not identic \\
\hline & negative control & 0.010 & Sig. $<0.05$ & Identic mean \\
\hline & $25 \%$ & 0.281 & Sig.> 0.05 & Mean not identic \\
\hline & $35 \%$ & 0.025 & Sig. $<0.05$ & Identic mean \\
\hline \multirow[t]{4}{*}{$25 \%$} & pellet & 0.135 & Sig.> 0.05 & Mean not identic \\
\hline & negative control & 0.000 & Sig. $<0.05$ & Mean identic \\
\hline & $15 \%$ & 0.231 & Sig.> 0.05 & Mean not identic \\
\hline & $25 \%$ & 0.754 & Sig.> 0.05 & Mean not identic \\
\hline \multirow[t]{4}{*}{$35 \%$} & Pellet & 0.015 & Sig. $<0.05$ & Identic mean \\
\hline & negative control & 0.000 & Sig. $<0.05$ & Identic mean \\
\hline & $15 \%$ & 0.023 & Sig. $<0.05$ & Identic mean \\
\hline & $5 \%$ & 0.751 & Sig.> 0.05 & Mean not identic \\
\hline
\end{tabular}

From the results of tables 3 and 4 above, the value of the increase in catfish weight every 1 week at each concentration value $>0.05$, which means there was no significant average difference. A value $<0.05$ means that there was a significant average difference. The results of the post hoc test analysis showed that between a concentration of $25 \%$ and a concentration of $15 \%$, there was no average difference in the increase in weight each week. The average statistical test results showed that the $35 \%$ formulation of catfish weight increase is the most optimal.

\section{DISCUSSION}

The results obtained at the demineralization stage were mass reduction. The lack of chitin yield at the demineralization stage is caused by the dissolving of the protein content in the shells of the chitin during the heating process using $\mathrm{NaOH}$ solution. In this process, there was a change in the color of the blood clam shells, which were initially white to light brown. This is because the $\mathrm{NaOH}$ solution is corrosive so that it can damage the dye contained in the shells. The reduction in the amount of chitin is caused by the evaporation of the chitin 
substance during the heating process using $\mathrm{NaOH}$ solution. The high temperature causes the acetyl group to be separated from the chitin structure, leaving a free amine group to bind to hydrogen (Susanti, Happy Nursyam 2013). High $\mathrm{NaOH}$ concentration will increase the number of acetyl groups released from chitin, thereby increasing the degree of deacetylation of chitosan. Low temperature will slow down the reaction rate. Based on research conducted by (Rosa Dewi Pratiwi, Siska Ela Kartika, and Widodo 2008), the effect of temperature and heating time on the deacetylation process of chitin will reduce the yield of chitosan. This is because the high temperature will cause the molecular chains in chitosan to depolymerize and result in a decrease in molecular weight and chitosan yield (E. Cahyono 2018).

The deacetylation process of Polymesoda erosa shell waste granules to remove the acetyl $\left(\mathrm{CoCH}_{3}\right)$ groups from chitin used alkaline solutions (Patil RS 2000). The deacetylation process of each chitin from Polymesoda erosic chitosan shell waste granules was different depends on the type of the shellfish. In addition, the deacetylation process involved was affected by the temperature and duration of the deacetylation process of the Polymesoda erosa waste. Deacetylation of Polymesoda erosa waste chitosan could increase due to the accuracy of the deacetylation process time and temperature. The time and temperature of the deacetylation process should be $70-75^{\circ} \mathrm{C}$ for 2 hours so that the yield of Polymesoda erosa chitosan is maximum (Masruriati et al. 2019).

The granules are made to smell fishy. The color of the granules resulted from this study was caused by chitosan mixed with bran, so the resulting color was light brown. The fishy smell of blood clam shell chitosan granules is caused by the bran ingredients are mixed slightly using fish profit so that the results of the granule aroma are like fish pellets, the purpose of using profit mixed with bran is to attract the fish to eat it.

The test of moisture content and drying shrinkage of granules was also conducted. The results showed that the negative control is the most humid from a concentration of $10 \%, 15 \%, 20 \%$, because the moisture content requirement is between 2-4\% (Lachman, L. H.A. 1994). Excessive moisture content in granule formulations can cause the granules to become hydrophobic so that the granules are difficult to float. In addition, if the granules have excessive moisture content, the granules will be easily overgrown by microbes.

The results of the compressibility value of the formula above indicated that the value of $11 \%$, $10 \%$, and $15 \%$ were in the good category, while the value of $16 \%$ was not in the good category, but is close to the good category. Compressibility value below $15 \%$ usually gives good flow properties and if the compressibility value is above $15 \%$, it indicates poor flowability (Susanti, Happy Nursyam 2013).

\section{CONCLUSION}

Granules of chitosan Polymesoda erosa can be used as a feed supplement to increase the weight of catfish with the most optimal concentration of $35 \%$.

\section{REFERENCES}

Afranita, Anita, and Hanifah. 2014. "Potensi Abu Cangkang Kerang Darah (Anadara Granosa) Sebagai Adsorben Ion Timah Putih.” vol. 01, no. 01, pp. 1-5.

Ariyanti et al. 2019. "Gambaran Perbandingan Kadar Rendemen Kitosan Cangkang the Effect of Base Concentration on Chitin Changes Into Chitosan on Shellfish Shell Waste and Milkfish Spines.” 8(1): 9-14. 
Ariyanti Ariyanti, Nita Fajaryanti, Arin Widya Nuari, Muhammad Himawan, and Yoga Syahputra. 2019. "Gambaran Perbandingan Kadar Rendemen Klitosan Cangkang Pada Anadara Antiquata Dengan Chanos Chanos Forsk." Jurnal Farmasetis Sekolah Tinggi Ilmu Kesehatan Kendal 8(1): 9-14.

E. Cahyono. 2018. "Karakteristik Kitosan Dari Limbah Cangkang Udang Windu (Panaeus Monodon).” Akuatika Indones., vol. 3, no. 2, p. 96, doi: 10.24198/jaki.v3i2.23395.

Kasim, S. 2013. "Pengaruh Variasi Jenis Pelarut Asam Pada Ekstraksi Kolagen Dari Ikan Pari (Himantura Gerrardi) Dan Ikan Tuna (Thunnus Sp)." Majalah Farmasi dan Farmakologi, Fakultas Farmasi Universitas Hasanuddin, Makassar.

Lachman, L. H.A., and Kanig. 1994. Teori Dan Praktek Farmasi Industri.

Masruriati, Eni et al. 2019. "Ekstraksi Kolagen Dilakukan Dengan Presipitasi Secara Salting out Dengan." 8(2): 99-108.

Patil RS, and Deshpande M. 2000. "Chitinolytic Enzymes an Exploration." Enz Microb Technol 26:473-483.

Rosa Dewi Pratiwi, Ari Eka Suryaningsih, Fauzi Alhidayat dan Heri Siska Ela Kartika, and Widodo. 2008. "Pelatihan Pembuatan Chitosan Dari Limbah Udang Sebagai Bahan Pengawet Alami Untuk Memperlama Daya Simpan Pada Makanan Di Kelurahan Pucangsawit." Proposal PKMM Dikti, Universitas Sebelas Maret, Surakarta.

Susanti, Happy Nursyam, dan Anik Martinah. 2013. "Effect of Chitosan Modified Process from Shrimp Shell (Littopenaeus Vannamei) toward the Fat Oxidation of Tuna Fish Fillet (Thunus Thunus)." J. Life Sci. Biomed. 3(3): 264-267, 2013 Fisheries and Marine Faculty, University of Brawijaya, Indonesia.

T. Masindi and N. Herdyastuti. 2017. "Karakterisasi Kitosan Dari Cangkang Kerang Darah (Anadara Granosa).” J. Chem., vol. 6, no. 3, pp. 137-142. 
Indonesian Journal of Global Health Research, Vol 3 No 1, February 2021, pp. 1 - 8 Global Health Science Group 